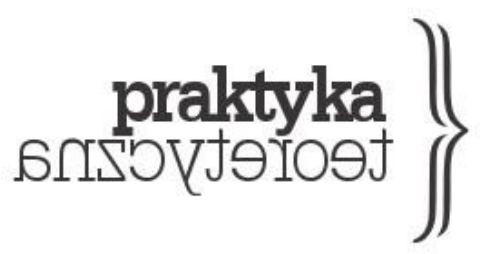

ISSN 2081-8130

DOI: 10.14746/prt.2017.3.16 www.praktykateoretyczna.pl

\title{
SCHIZOFRENICZNA MATERIA. O PRODUKCJI CIAL, POJĘĆ I PODMIOTOWOŚCI
}

\author{
BARTOSZ MROCZKOWSKI
}

\begin{abstract}
Abstrakt: Realizm sprawczy jest współczesnym stanowiskiem, mieszczącym się w obrębie nowego materializm i posthumanizmu, łączącym zagadnienia $\mathrm{z}$ zakresu filozofii i fizyki. Jego twórczyni, Karen Barad, feministyczna myślicielka, wiąże ze sobą rozważania z zakresu poststrukturalizmu (Michel Foucault), krytycznych teorii feministycznych z odkryciami współczesnej fizyki kwantowej, wynikającymi z twierdzeń przyjętych przez jednego z fundatorów tej dziedziny wiedzy - Nielsa Bohra. Celem artykułu jest ukazanie pokrewieństw zachodzących pomiędzy realizmem sprawczym oraz rozważaniami Deleuze’a i Guattariego, przedstawionym w Anty-Edypie. Autor skupia się na zaprezentowaniu procesualnej ontologii (objaśnieniu w jaki sposób produkowane są ciała, pojęcia i przedmioty) wynikającej z zazębiania się obydwóch stanowisk.
\end{abstract}

Słowa kluczowe: materia, realizm sprawczy, Karen Barad, nowy materializm, Anty-Edyp, posthumanizm, performatywność, Deleuze i Guattari, feminizm, poststrukturalizm. 
Realizm sprawczy, stanowisko metafizyczne zaproponowane przez Karen Barad, mieszczące się w obszarze rozważań posthumanizmu i nowego materializmu, wiąże ze sobą wybrane zagadnienia z zakresu fizyki kwantowej i myśli feministycznej oraz poststrukturalizmu. Jak pisze badaczka, materia zaczyna mieć znaczenie (Matter Comes to Matter), bo materialna produkcja znaczeń konstytuuje pojęcia, ciała i podmioty ${ }^{1}$. Celem niniejszego artykułu jest przedstawienie, w jaki sposób dociekania Gilles' a Deleuze' a i Féliksa Guattariego zaprezentowane w Anty-Edypie oraz myśl Michela Foucaulta wybrzmiewają w systemie realizmu sprawczego.

Realizm sprawczy jest rodzajem kłączo-myślenia, czyli działania mającego na celu powiązanie tego, co ludzkie i nie-ludzkie. Wspólnota znaczących innych rozszerza się: zwierzęta, ludzie, rośliny, rzeczy, zachodzące pomiędzy nimi relacje wyłaniają się z materialnej produkcji znaczeń. Barad, podobnie jak inne przedstawicielki feministycznych teorii krytycznych, takie jak Rosi Braidotti czy Donna Haraway, podejmuje próbę przekroczenia języka jako tego, co znaczące. Pytanie stawiane przez badaczkę za Deleuze' em, Guattarim i Foucaultem brzmi: w jaki sposób znaczenia wytwarzają się w materialnej produkcji?

\section{Intra-akcyjna produkcja fenomenów-maszyn}

Punktem wyjścia dla Barad są rozważania Nielsa Bohra. Duński naukowiec jest jednym z twórców interpretacji kopenhaskiej, wykładni zjawisk rozpatrywanych w fizyce kwantowej (Barad 2012, 338). W rozważaniach Bohra widać bardzo silne przenikanie się treści z zakresu fizyki z poglądami filozoficznymi. Jest to również odczuwalne u Barad, która pisze o realizmie sprawczym jako o stanowisku filozoficzno-fizycznym. Bohr odrzucał metafizykę esencji/istoty, czyli przekonanie o istnieniu pierwotnych obiektów o zdeterminowanych właściwościach i granicach oraz zachodzących pomiędzy nimi wtórnych interakcjach. Na mocy tego założenia kartezjańskie oddzielenie instancji poznającej (podmiotu) od tego, co poznawane (przedmiotu), zostaje odrzucone. Fizyk proponuje, aby za pierwotne uznać procesy różnicujące, zwane przez niego intra-akcjami, które wytwarzaja granice i właściwości, konstytuując w ten sposób obiekty (Barad 2012, 339-340). Barad

1 W języku angielskim słowo matter to jednocześnie materia, jak i znaczenie. Barad bardzo często wykorzystuje tę wieloznaczność (Barad 2012, 323). 
podkreśla, że rozważania Bohra mają charakter epistemologiczny. Duński naukowiec stara się objaśnić, w jaki sposób zachodzi ludzkie poznanie oraz produkcja wiedzy. Celem Barad jest z kolei przemyślenie ontologicznych konsekwencji wynikające z tych założeń (Barad 2007, 122). Ze względu na to realizm sprawczy jest stanowiskiem onto-epistemologicznym (Barad 2007, 332).

Stanowisko Barad, zanurzone w metafizyce opartej na procesach konstytuujących obiekty, choć wypracowane niezależnie i w ramach różnych tradycji myślowych, pod wieloma względami jest zbieżne z rozważaniami Deleuze'a i Guattariego, przedstawionym w AntyEdypie (Deleuze i Guattari 2017, 74). Intra-akcyjna produkcja generuje układy o określonych granicach i właściwościach, które podlegają nieustannym (re)konfiguracjom, a pomiędzy nimi nieprzerwanie wytwarzają się nowe relacje (Barad 2007, 179). Wyłaniające się w ten sposób złożenia określane są mianem fenomenów. Podobnie jak pojęcie intra-akcji jest to termin zaczerpnięty od Bohra (Barad 2007, 56). Fenomeny, tak jak Deleuzjańsko-Guattariańskie układy maszynowe, konstytuuja się i wyrażają proces produkcji pragnącej. Intra-akcje, jako wzajemnie splątane, wytwarzają i wiążą ze sobą fenomeny. Kategoria splątania (entanglement) wywodzi się z fizyki kwantowej, którą Barad stara się włączyć w obszar posthumanizmu i nowego materializmu. Splątanie dotyczy takiego związku dwóch lub większej ilości zjawisk, $\mathrm{w}$ ramach którego zmiany $\mathrm{w}$ jednym $\mathrm{z}$ nich powoduja przekształcenia we wszystkich pozostałych (Barad 2007, 309). Intra-akcyjna produkcja pragnąca (wspó1)przekształca i (współ)wytwarza układy maszynowo-fenomenalne ${ }^{2}$. Barad-Bohr podkreślają, że pojęcia, w takim samym stopniu jak ciała oraz podmiotowości, sa materialnymi układami o nieustannie (re)konfigurowanych właściwościach i granicach.

\section{Metafizyka esencji i reprezentacjonizm}

Metafizyka esencji, czyli przekonanie o pierwotności określonych obiektów i interakcji między nimi, wprowadza nieprzekraczalne cięcie pomiędzy znaczeniem i materialnością. Istnieja dwie kategorie obiektów: poznające i poznawane. Ludzkie podmioty wytwarzaja

2 W jednym z wywiadów Barad, objaśniając zjawisko stanu wzbudzonego (excited state) w fizyce kwantowej, żartobliwie odnosi je do kategorii pragnienia. Nieosobowo pojmowane pragnienie jest obecne również na płaszczyźnie kwantowej (Dolphijn i Van der Tuin 2012, 63). 
wiedzę o obserwowanych przedmiotach. Stanowisko reprezentacjonistyczne kryje w sobie dwojakie założenie: instancja poznająca nie ma dostępu do poznawanych obiektów, ma natomiast dostęp do wytwarzanej na ich temat wiedzy/reprezentacji. Jak pisze Barad, spór pomiędzy realistami naukowymi i konstruktywistami społecznymi jest jałowy, ponieważ, pomimo pewnych różnic, obydwa te stanowiska bazują na tym samy założeniu: nie mamy dostępu do świata, lecz możemy wytwarzać na jego temat wiedzę, a za jej pomocą możemy ten świat przekształcać. W tym punkcie spór dotyczyć zaczyna dwóch kwestii. Z jednej strony pada pytanie: czy wiedza naukowa w sposób obiektywny odzwierciedla relacje zachodzące pomiędzy obiektami swoich badań oraz ich właściwości? Z drugiej zaś: w jaki sposób to, co kulturowo-społeczne, utożsamiane z językiem, konstruuje obserwowane obiekty? Zarówno Deleuze i Guattari, jak i Foucault byli zagorzałymi wrogami reprezentacjonizmu, zdając sobie sprawę, jak wielkie zagrożenie niesie ze sobą to stanowisko. Obiekty poznające i poznawane są od siebie oddzielone, zaś reprezentacja jest formą mediacji pomiędzy nimi. Jak powiedziałby Foucault, relacja między instancją poznająca a tym, co obserwowane, opiera się na asymetrycznym stosunku władzy. Wiedza jest wytwarzana tylko przez ludzkie podmioty i tylko one mają do niej dostęp. Poznawane obiekty są wytwarzane/opisywane w procesie znaczeniowym, lecz same nie maja nań wpływu. Pojęcia, jako formy ideacji, znacza/konstruują materialne rzeczy. Wiedza jest strukturą powiązanych ze sobą znaczeń, których funkcja polega na reprezentowaniu obiektów (świata). Barad, podobnie jak przed nią Deleuze i Guattari oraz Foucault, porzuca metafizykę esencji, aby w ten sposób wyzwolić się z władzy reprezentacjonizmu. Kiedy zrezygnujemy z uznania pierwotności rzeczy-słów oraz interakcji między nimi, a więc powrócimy do produkcji wytwarzającej produkty, wiedza przestanie być reprezentacją, a stanie się aktywnością performatywna. Wiedza jest fenomenem konstytuującym się w procesie intra-akcyjnej produkcji, której ludzka aktywność jest jednym z wielu przejawów. Zarówno instancja poznająca, jak i to, co poznawane, sąwytwarzane i wtórne wobec procesów, które powoduja ich wyłanianie się. Relacja podmiot-przedmiot jest tylko chwilowym maszynowym układem, który podlega ciagłym (re)konfiguracjom.

Produkcja pragnąca Deleuze’a i Guattariego, podobnie jak procesy intra-akcji Barad, jest ruchem materialnych znaczących procesów, warunków wykraczających poza ludzkie świadome i celowe działania. Podobne znaczenie kryje w sobie pojęcie praktyk dyskursywnych, za pomocą którego Foucault stara się wytworzyć powiązanie pomiędzy 
ciałami i znaczeniami. Działania takie jak mierzenie, pisanie, czytanie, mówienie itp., jako produkcja materialnych znaczeń, konstytuują ludzkie ciała (Barad 2007, 62-63). Praktyki dyskursywne maja charakter historyczny - wytworzyły się w określonych warunkach społecznych, ekonomicznych i geograficznych. Produkcja znaczeń dokonuje się poprzez wskazanie elementów istotnych oraz wykluczenie pozostałych czynników, którym odbiera się sprawczość. Proces zawężenia, poprzez wyznaczenie granic i właściwości, powoduje wyłonienie się ciał. Żołnierz żyjący w koszarach, podobnie jak zakonnik w klasztorze, żyje w wyznaczonej dla niego przestrzeni, w której poddawany jest określonym procedurom i oddaje się codziennym rutynowym czynnościom. Pobudka zawsze o tej samej godzinie powoduje, że jego cykl biologiczny jest uregulowany. Dzień rozpoczyna się od zwyczajowej musztry, odbywającej się zawsze według tego samego schematu, po której następuje złożenie meldunku przed przełożonym. Tworzy się sztywna hierarchia pomiędzy poszczególnymi osobami. Wszystkie te procesy prowadzą do ukonstytuowania się określonego typu podmiotowości (Foucault 2009, 131-165).

Jak podkreśla Barad, Foucault pokazuje, w jaki sposób praktyki dyskursywne, będąc tym, co społeczno-kulturowe, kształtuja, formuja i wytwarzają ciała. Autorowi Nadzorować i kará́, pomimo podejmowanych przez niego prób, nie udaje się ukazać sprawczości ciał (materialności). Praktyki dyskursywne jako procesy wytwarzania znaczeń mają materialny charakter, przekształcają ciała, co jednak z aktywnością samych ciał (Barad 2007, 65-66)? Asymetryczna relacja pomiędzy praktykami dyskursywnymi i ciałami u Foucaulta polega na tym, że ciała podlegaja znaczeniowym przekształceniom, lecz same nie wpływaja na wyłaniające się znaczenia. Znaczenia w tym układzie nie są wytwarzane przez same materialne ciała. Pomiary, mowa, pismo sa procesami upodmiotawiania, które zachodzą na poziomie cielesnym, materia jest kształtowana przez praktyki dyskursywne. Próba powiązania znaczenia i ciała w proces produkcji podjęta przez Foucaulta jest niekompletna. Rozważania francuskiego myśliciela ogranicza jeszcze jeden czynnik, mianowicie interesuja go wyłącznie ludzkie ciała, co w perspektywie badań prowadzonych w posthumanizmie i nowym materializmie jest istotnym uchybieniem. Przepaść pomiędzy znaczeniowością i cielesnością nie zostaje zniesiona.

Barad proponuje rozszerzenie pojęcia Foucaulta do praktyk materialnodyskursywnych. Proces materialnej produkcji znaczeniowej, intra-akcji, powoduje, o czym była już mowa, konstytuowanie się fenomenów o określonych granicach i właściwościach 
(Barad 2007, 212). Opisana w Anty-Edypie produkcja pragnąca, wytwarzająca maszynowe układy, oraz intra-akcyjna produkcja fenomenów, zawarta w koncepcji realizmu sprawczego, są procesami samoprzekształcania się znaczącej materii. Wytwarzanie pojęć, ciał i podmiotowości jest produkcją znaczeń w procesie materializacji. Działania przedstawicielek nowego materializmu, takich jak Karen Barad, podobnie jak rozważania Deleuze' a i Guattariego, skupiają się na uchwyceniu aktywności znaczeniowej tego, co materialne.

Barad posługuje się również pojęciem stosunków władzy Foucaulta, które pozwala na przeanalizowanie, w jaki sposób możemy wyzwolić aktywność materialności w naszym myśleniu. Autor Historii seksualności twierdził, że pojęcie władzy samo w sobie nie ma charakteru negatywnego. Francuski myśliciel podkreślał równocześnie, że w swoich badaniach nie utożsamia on władzy z instytucjami takimi jak państwo, partia, czy rodzina. Placówki zajmujące się osobami uznanymi za chore psychicznie lub zakłady karne, w których przetrzymuje się więźniów skazanych wyrokiem sądu, bardzo często utożsamiane są z emanacja opresyjnej władzy. Foucault skupia się na relacjach i zależnościach, które konstytuują te właśnie instytucje, czyli na stosunkach władzy. Filozof był jednocześnie zainteresowany tym, w jaki sposób możemy dynamizować stosunki władzy, nie doprowadzając do ich skostnienia w postaci stanu dominacji (Foucault 2013, 225-227). Barad, korzystając z analiz Foucaulta, ukazuje, w jaki sposób z intra-akcyjnej produkcji wyłaniają się specyficzne stosunki władzy, oparte na ludzkich i nie-ludzkich połączeniach.

\section{Przeciw Edypowi}

Deleuze i Guattari przedstawiają, na czym polega działanie trójkąta edypalnego. Celem psychoanalizy jest petryfikacja produkcji pragnącej poprzez wtłoczenie jej w układ mamatata-ja oraz ustabilizowanie relacji zachodzących między figurami tego układu (Deleuze i Guattari 2017, 51). Interakcje te wyrażają ujarzmienie zapętlonej i spętanej produkcji nieświadomości (Deleuze i Guattari 2017, 29).

Zestawiając ze sobą rozważania Barad oraz Deleuze’ a i Guattariego, można pokazać, że produkcja pragnąca jest procesem stawania się słów, ciał i podmiotowości. Nieświadomość generuje różne formy relacyjności. Produkcja pragnąca nie jest teleologiczna, a więc wbrew Freudowi jej celem nie jest uformowanie się trójkąta edypalnego. Zjawiska 
opisywane przez psychoanalityków jako zaburzenia psychiczne nie sa przejawami psychicznej degeneracji, lecz wynikiem nadprodukcji materialnych znaczeń, przelewających się poza granice Edypa (Deleuze i Guattari 2017, 52). Należałoby dopowiedzieć, że nieświadomość, jako nieprzerwanie dokonujące się materializacje, nie jest procesem przemian, w którym w każdym momencie mogą wydarzyć się całkowicie dowolne przekształcenia (Deleuze i Guattari 2017, 55, 67-68). Intra-akcyjna produkcja, konstytuująca fenomeny w postaci słów, rzeczy i podmiotowości, modyfikuje istniejącą w danym momencie potencjalność.

Istotą materialistycznej psychiatrii, zaproponowanej przez Deleuze' a i Guattariego, jest połączenie pragnienia i produkcji. Jak powiedziałaby Barad, stająca się materia przeistacza się, procesy intra-akcji dokonują cięć znaczeniowych, co powoduje wyłanianie się ucieleśnionych podmiotów (Barad 2007, 141). Materialistyczna psychiatria „[...] określa się [...] poprzez podwójną operację: wprowadzenie pragnienia do mechanizmu i wniesienie dziedziny produkcji do pragnienia" (Deleuze i Guattari 2017, 28). Rozważania autorów AntyEdypa skupiaja się na społeczno-ekonomicznym aspekcie produkcji pragnącej. Materialne maszyny konstytuuja pole społeczne i warunki ekonomiczne (Deleuze i Guattari 2017, 319_ 330). Intra-akcyjne procesy znaczeniowe przeciekaja przez granice triangularnej edypalnej struktury, wytwarzając schizofreniczne podmiotowości, ciała i pojęcia (Deleuze i Guattari 2017, 54).

Zdaniem autorów Anty-Edypa jednym z głównych błędów Freuda było przyjęcie w psychoanalizie podstawowego założenia w postaci odwróconej przyczynowości: produkt generuje produkcje (Deleuze i Guattari 2017, 64-65). Jest to o tyle szkodliwe posunięcie, że przysłania ono molekularny wymiar produkcji oraz wytwarza iluzję samoistności obiektów. Edyp jako produkt, pierwotna triangularna struktura, istnieje zawsze, nawet wtedy, kiedy zachodzą w jego wnętrzu pewne zmiany (interakcje). Niektóre z przekształceń są uznawane za wadliwe i określane mianem psychicznych zaburzeń. Bycie schizofrenikiem sprowadza się do określonych, skatalogowanych zaburzeń: urojeń, halucynacji itp. „Ja” jest edypalne nawet wtedy, kiedy przejawia swoje ,zaburzenie”. Posługując się myślą Barad-Bohra, można uznać, że psychoanaliza jest ufundowana na metafizyce esencji $1^{3}$. W ramach tego paradygmatu istnieja zdeterminowane obiekty, tożsamości, które wytwarzaja znaczenia. Schizofrenik, jako „ja” o zdefiniowanych granicach, składa się z określonych zaburzeń psychicznych. Psychiatra posiada wiedzę o tym, czym jest schizofrenia, i dokonuje kwalifikacji przez rozpoznanie jej

3 Wyjątkiem jest strukturalistyczna psychoanaliza lacanowska. 
przejawów-objawów. Schizofrenik już jest, trzeba go tylko zdiagnozować, wskazać. Wiedza jest reprezentacja gotowych istnień. Obiektywność jest sztuką odzwierciedlania rzeczy i wytwarzania ich obrazów.

Krytyka metafizyki esencji jest pierwszym krokiem na drodze do wyzwolenia się z władzy reprezentacji. Schizofrenik jako obiekt obserwacji nie istnieje. Psychiatra, poddając diagnozie pacjenta, konstruuje schizofrenika w procesie wytwarzania znaczeń. Zaburzenia psychiczne są kulturowo-historycznymi konstruktami, powstającymi w wyniku aktywności ludzkich podmiotów. Wytwarzanie wiedzy nie jest aktywnością polegająca na odzwierciedlaniu obiektów, lecz ich nieustannym przekształcaniu. Reprezentacjonistyczne rozdzielenie, pomiędzy tym, co poznawane i tym, kto poznaje, pozostaje w mocy. Ludzkie podmioty kształtują obiekty, lecz same nie sa przez nie przekształcane. Zbieżność krytyki reprezentacjonizmu Deleuze'a i Guattariego oraz Barad, zarówno w postaci realizmu naukowego, jaki i konstruktywizmu społecznego, opiera się o przywrócenie pierwotności produkcji względem produktu. Schizofrenik wyłania się z produkcji pragnącej. Ludzkie i nieludzkie intra-akcje konstytuują schizofrenika jako rodzaj fenomenu (układu maszynowego). Nie ma żadnej pierwotnej istoty, która była by opisywania („schizofrenik już jest, trzeba go tylko zdiagnozować”), ani też nie jest ona kształtowana przez instancje poznające, jako coś oddzielonego od nich („schizofrenik jest wytwarzany przez to, co społeczne i kulturowe, rozumiane jako wyraz aktywności ludzkich podmiotów”). Splątane intra-akcje konstytuują instancję poznająca, jak i to, co poznawane, jako fenomeny-maszyny, które wzajemnie się przekształcają, wyrażając w ten sposób proces materialnej produkcji znaczeń (stającej się materii). Reprezentacjonistyczne oddzielenie tego, co poznawane i tego, co poznające zostaje zniesione.Jak było już powiedziane wcześniej, Anty-Edyp, podobnie jak realizm sprawczy, stanowi próbę przywrócenia pierwszeństwa produkcji względem produktu. Schizofrenik, tak jak każda inna forma ,ja” - „zaburzona” czy „niezaburzona” - jest wyrazem intraakcyjnego konstytuowania się fenomenów (maszyn pragnienia) (Deleuze i Guattari 2017, 61). Produkcja pragnąca materializuje się, wytwarzając materię w postaci różnych form podmiotowości, które to same sa przejawami procesu produkcji (Deleuze i Guattari 2017, 29-30). Nie istnieją zdeterminowane tożsamości wytwarzające znaczenia. 


\section{Schizofrenik i posthumanistyczna performatywność}

Rozważania Foucaulta, dotyczące stosunków władzy i praktyk dyskursywnych, oraz przemyślenia Deleuze' a i Guattariego na temat produkcji pragnacej są formami performatywnych teorii krytycznych. Słowa, rzeczy i podmioty nigdy nie sa dane, lecz wyłaniaja się w procesie samoprzekształceń materii. Barad zwraca uwagę, że działania performatywne nie są przywilejem wyłącznie ludzkim. Praktyki materialno-dyskursywne wyrażają splątanie ludzkich i nie-ludzkich procesów konstytuujących fenomeny. Wytwarzanie się zjawisk w ich historyczności zachodzi poprzez proces materializacji pojęć i ucieleśnionych podmiotowości (Barad 2007, 151-152, 183; Barad 2012, 344-348).

Binarne opozycje, ludzkie i nie-ludzkie, kultura i natura, wytwarzają się za sprawą splątania wielu procesów, aktywność ludzka jest jednym z nich, ale nie jedynym. Wyrazem tego powiązania w realizmie sprawczym jest myślenie w kategoriach posthumanistycznej performatywności, czyli połączenie znaczenia i materialności w intra-akcyjnej produkcji. Działania performatywne, wyznaczając ograniczenia, powodują wytwarzanie się cielesnych podmiotów i pojęć (Barad 2012, 335). Schizofrenik Deleuze’a i Guattariego jest wspólnota splątań tego, co ludzkie i nie-ludzkie, wyłaniającą się z produkcji pragnącej.

Słabym punktem rozważań Foucaulta, o czym była już mowa, jest fakt, że ograniczają się one tylko do ludzkiej aktywności i obejmują jedynie wytwarzanie ludzkich ciał. $\mathrm{Na}$ podstawie lektury Anty-Edypa podobne zarzuty można by wysunąć wobec Deleuze' a i Guattariego, zwracając uwagę, że autorzy obejmują w swoich rozważaniach domenę tego, co ludzkie i społeczne, pomijając całkowicie nie-ludzkie aktywności. Jednak lektura drugiego tomu Kapitalizmu i schizofrenii, Tysiaca plateau ujawnia, że ontologia zaproponowana przez duet francuskich myślicieli ma na celu ukazanie powiązań pomiędzy tym, co ludzki i nie-ludzkie, wykraczając daleko poza to, co społeczne.

4 Zarówno dla Deleuze i Guattariego, jak i Barad to co społeczne nie ogranicza się do relacji międzyludzkich, lecz jest tym, co wyłania się i wyraża produkcję pragnąca, czyli splatania ludzkich i nie-ludzkich intra-akcji. 


\section{Wykaz literatury}

Barad, Karen. 2007. Meeting the Universe Halfway: Quantum Physics and the Entanglement of Matter and Meaning. Durham: Duke University Press Books.

Barad, Karen. 2012. „Posthumanistyczna performatywność: ku zrozumieniu, jak materia zaczyna mieć znaczenie”. Tłum. Joanna Bednarek. Teorie wywrotowe. Red. Agnieszka Gajewska. Poznań: Wydawnictwo Poznańskie.

Deleuze, Gilles i Félix Guattari. 2017. Anty-Edyp. Tłum. Tomasz Kaszubski. Warszawa: Wydawnictwo „Krytyki Politycznej”.

Deleuze, Gilles, i Félix Guattari. 2015. Tysiąc plateau. Red. meryt. Joanna Bednarek. Warszawa: Fundacja Nowej Kultury Bęc Zmiana.

Foucault, Michel. 2012. Kim pan jest, profesorze Foucault?. Tłum. Kajetan Maria Jaksender. Red. Bartłomiej Błesznowski, Kajetan Maria Jaksender, Krzysztof Matuszewski. Kraków: Wydawnictwo Eperons-Ostrogi.

Foucault, Michel. 2009. Nadzorować i karać. Tłum. Tadeusz Komendant. Warszawa: Wydawnictwo Aletheia.

Ven der Tuin, Iris i Rick Dolphijn. 2012. New Materialism. Interviews \& Cartographies. Ann Arbor: Open Humanities Press. 
Bartosz Mroczkowski - doktorant w Instytucie Filozofii UAM w Poznaniu, gdzie zajmuje się tematem konceptualizacji i praktyk ciała w perspektywie posthumanizmu i nowego materializmu (2013). Absolwent kierunku filozofia w IF UMK w Toruniu (2011): praca dyplomowa Anty-psychiatria: filozofia $i$ praktyka. Założyciel i redaktor portalu internetowego Machina Myśli. Razem z Krystyną „Lamą” Szydłowską organizował transdyscyplinarne warsztaty „Praktyka kształtowania wiedzy w ruchu”. Jego zainteresowania badawcze skupiaja się wokół poststrukturalizmu i zagadnienia stawania się (Gilles Deleuze i Félix Guattari), życia w ogóle (zoe), posthumanizmu, feministycznych teorii krytycznych, nowego materializmu, estetyki egzystencji, anty-psychiatrii i szeroko rozumianej cielesności oraz eksperymentów z nią związanych. Razem z fundacją „Sens Ruchu” organizował cykl warsztatów „Affects and Micropolitics - pool for practice exchange”. Publikował w Machinie Myśli, eCzasKultury oraz serii naukowej Scripta IFK UW.

\section{DANE ADRESOWE:}

Instytut Filozofii

Uniwersytet im. Adama Mickiewicza

ul. Szamarzewskiego 89 C

60-568 Poznań

EMAIL: bartosz.mroczkowski86@gmail.com

CYTOWANIE: Bartosz Mroczkowski. 2017. Schizofreniczna materia. O produkcji ciał, pojęć i podmiotowości. Praktyka Teoretyczna 3(25): 342-353.

DOI: $10.14746 /$ prt.2017.3.16

\section{AUTHOR: Bartosz Mroczkowski}

TITLE: Schizophrenic Matter. About the Production of Bodies, Concepts and Subjectivities

ABSTRACT: Agential realism is a perspective situated within the new materialism and posthumanism which combines philosophical and physical issues. Karen Barad, feminist thinker and creator of agential realism, mixes poststructuralist ideas (Michel Foucault) and feminist critical theories with quantum physics, in particular with the thesis of Niels Bohr, one of the founders of this field. The main purpose of this article is to show the relations between agential realism and ideas presented by Deleuze and Guattari in one of their most famous books - Anti-Oedipus. The author of the paper focuses on the presentation of a 
processual ontology (especially on an explanation of how bodies, concepts, and objects are produced) resulting from the engagement of both perspectives.

KEYWORDS: matter, agential realism, Karen Barad, new materialism, Anti-Oedipus, posthumanism, performativity, Deleuze and Guattari, feminism, poststructuralism. 